\title{
THE ROLE OF EXERCISE ECG TEST IN DETERMINING THE SEVERITY OF CORONARY HEART DISEASE AND THE JEOPARDY OF MYOCARDIUM
}

\author{
Khalid Ghanim Hameed Al-abachi \\ Mosul Center for cardiology and cardiac surgery \\ Correspondence: khalid.abachi@gmail.com
}

(Ann Coll Med Mosul 2020; 42 (1):68-75).

Received: $18^{\text {th }}$ April 2020; Accepted: $19^{\text {th }}$ July 2020.

\begin{abstract}
Objective: To assess the value of exercise ECG test in evaluating the severity of coronary artery disease and jeopardy of myocardium .

Methods: A prospective study of 75 consecutive patients were all had history of angina, and they underwent both treadmill test (TMT) and coronary angiography in Mosul Center for Cardiology and Cardiac Surgery in the priod from April 2013 to August 2014 .Those with significant angiographic coronary artery stenosis (61 patients) were divided into four groups according to the size of myocardium supplied by and the resulting jeopardized myocardium. This division depends on identity of involved vessel, number of vessels and the site of the lesion on the involved vessel. Also, the result of TMT with ST depression was classed into class A (ST segment depression involving $\geq 5$ leads) and class B (ST depression involving $<5$ leads). Correlation between the angiographic groups and the results of TMT regarding the number of leads showing ST changes was done.

Results: The study involved $53(70.5 \%)$ male and $22(29.5 \%)$ female patients. The sensitivity and specificity of TMT were $77 \%$ and $71.5 \%$, respectively. There were significant difference between class A and class B in patients with group I angiographic changes (which is the most severe angiographic coronary artery lesions and the largest jeopardized myocardium) and in patients $w$ ith group IV (which is the least severe of coronary lesions with the smallest jeopardized myocardium). These differences became more significant after excluding patients with myocardial infarction (MI) and/or patients who develop severe typical angina (STA) at low workload which preclude continuation of test before appearance of the ECG changes of ischemia. Also w hen comparing group I, II or III separately or collectively with group IV we noticed significant differences regarding both class $\mathrm{A}$ or class $\mathrm{B}$, especially after excluding patients with $\mathrm{MI}$ and/or patients with STA at low workload.
\end{abstract}

Conclusion: Our data suggest that exercise ECG test can b e useful in determining the severityof coronary artery disease and size of jeopardized myocardium rather than the location of lesion or number of vessels involved.

Key words : coronary artery disease, exercise ECG test, coronary angiography .

$$
\begin{aligned}
& \text { دور فحص إجهاد القلب مع التخطيط الكهربائي في تقيم شدة } \\
& \text { قصور الثرايين التاجية و مدى تعرض العضلة القلبية للخطورة } \\
& \text { خركز الموصل لطب حميل العباجي القبل }
\end{aligned}
$$

اللهاف : تحديد قيمة فحص إجهاد القلب مع التخطيط الكهربائى فى تقيم شدة قصور الثر ايين التاجية ومدى تعرض العضلة القلبية

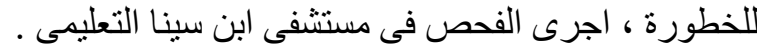

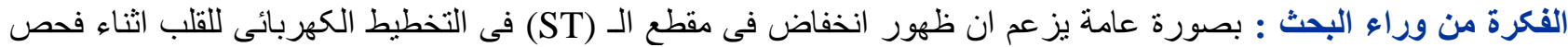

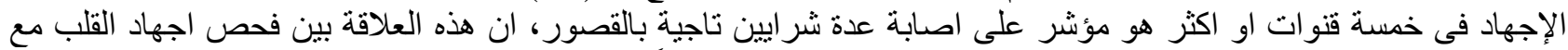

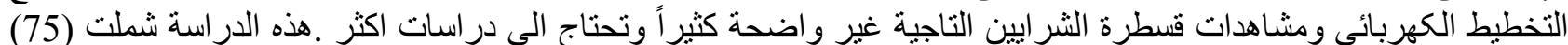

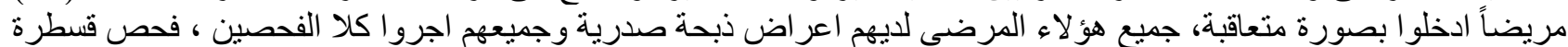

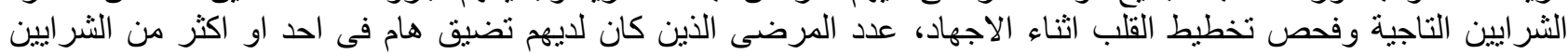




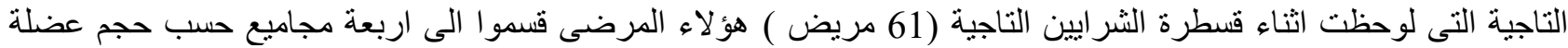

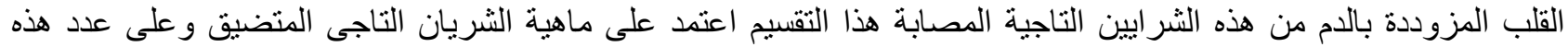

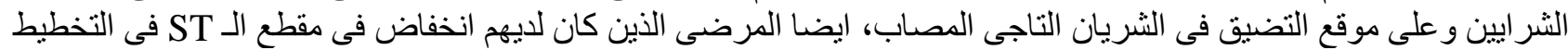

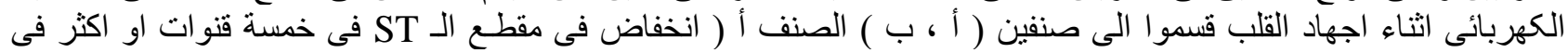

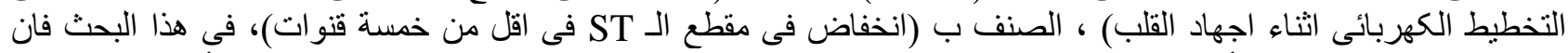

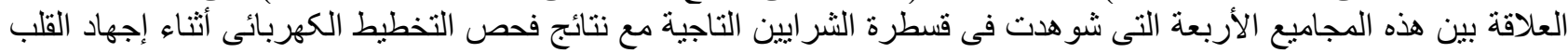

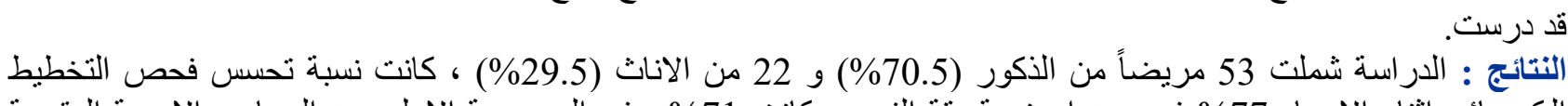

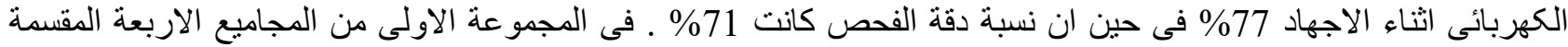

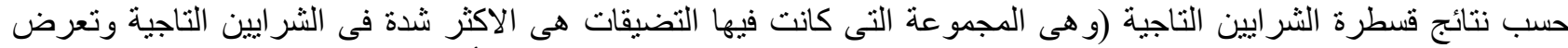

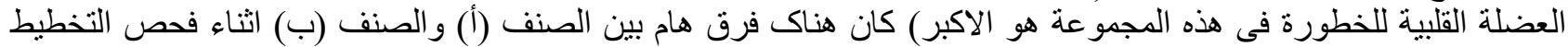

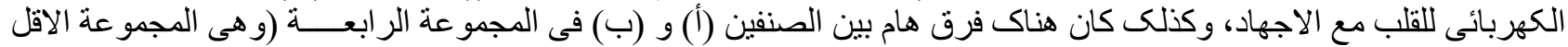

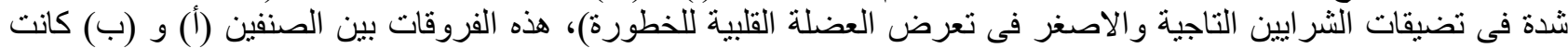

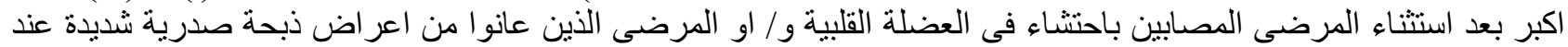

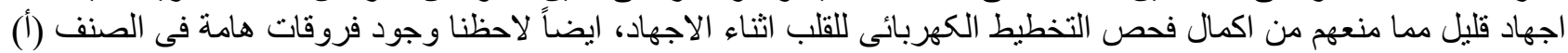

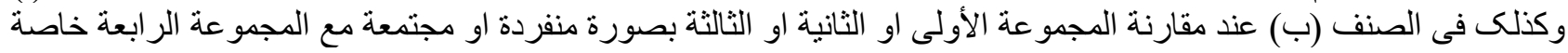

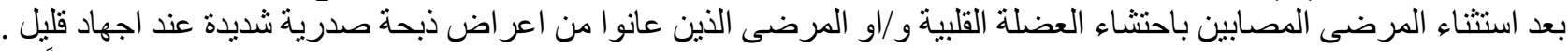

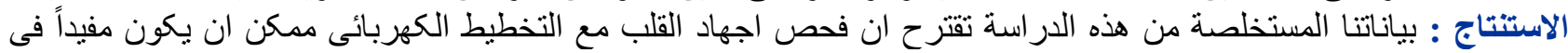

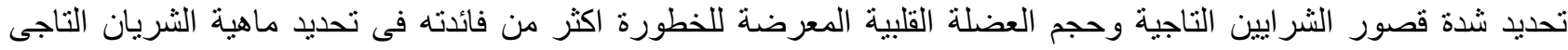

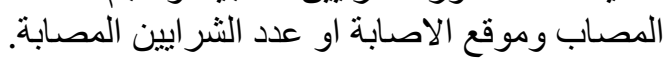

الكلمات المفتاحية : قصور الثرايين التاجية ، فحص إجهاد القلب مع التخطيط الكهربائى ، قسطرة الثر ايين التاجية.

\section{INTRODUCTION}

- or several decades, stress evaluating patients suspected of having coronary artery disease (CAD). It is one of the most frequent non-invasive modalities.

Exercise is a common physiological stress used to elicit cardiovascular abnormalities not present at rest and determine the adequacy of cardiac function ${ }^{1}$. The standard Bruce protocol is popular, and a large diagnostic data base has been published using this protocol ${ }^{2,3}$.

Many investigators have correlated the results of stress testing with coronary angiographic finding in an effort to identify patient with critical forms of CAD for further diagnostic and therapeutic considerations ${ }^{4,5}$

The exercise ECG test can give wide variability on sensitivity and specificity. A meta-analysis of 147 consecutively published reports involving 24074 patients who underwent both coronary angiography and exercise testing revealed a wide variability in sensitivity and specificity (mean sensitivity was $68 \%$ with a range of $23 \%$ to $100 \%$ and a standard deviation of $16 \%$; mean specificity was $77 \%$ with a range of $17 \%$ to $100 \%$ and a standard deviation of $17 \%)^{2}$.

Many studies concentrate on the correlation between the number of coronary arteries diseased in angiography and with the degree of ST segment depression, with haemodynamic response of patient during stress test, with development of angina pectoris at low exercise workload, or with the number of leads showing ST segment depression in exercise ECG test. Most of these studies noticed positive correlation between these parameters and multivessel disease ${ }^{2,3,6}$.

Other studies said that patients exhibiting ST segment depression in 5 leads or more are more likely to be associated with multivessel disease ${ }^{7-}$ ${ }^{9}$.This study concentrates on the correlation between the size of jeopardized myocardium as determined angiographically by the site, number, and location of coronary artery stenosis with the number of leads showing ST depression during exercise ECG test. And the purpose of this study is to test the concept that it is the size of jeopardized myocardium that determins the result of TMT in term of number of leads that show ST segment depression rather than the identity of coronary artery or the mere number of vessels involved. 


\section{Materials and Methods}

This prospective study was initiated on April 2, 2013 and was terminated on August 15, 2014. A total of consecutive (850) patients were studied by TMT during this period; of these, only (149) patients underwent coronary angiography in Mosul Center for Cardiology and Cardiac Surgery and out of this number, only (75) patients were included in this study, and the remainder (74) were excluded. Those patients were patient who cannot reach $85 \%$ of predicted target heart rate and without developing ST-depression in any lead (undiagnostic test), patients with pre-TMT STsegment depression of $\geq 1 \mathrm{~mm}$, patients with left bundle branch block and left ventricular hypertrophy, patients with pre-excitation syndrome, patients with valvular heart diseases and patients on $\square$-bockers or digoxin because these situations can change the sensitivity and specificity of the test 10

In these 75 included patients, a history of angina pectoris was given by all patients. Standard electro-cardiograms and TMT as well as angiographic findings were analyzed. The period between TMT and coronary angiography was as long as 3 months.

\section{Treadmill Exercise Testing}

Treadmill exercise testing (TMT) was performed according to the Bruce protocol, using the graded multistage treadmill. Exercise was continued for 3 minutes at each stage. A standard 12-lead ECG was performed before exercise and at 1-minute intervals for a period of 5-10 minutes during exercise and 3 minutes after exercise. During exercises, 3 precardial leads were monitored continuously, and 12-lead ECG was recorded at the end of each stage. Cuff blood pressure measurements were made at the same intervals. Patient were encouraged to exercise to the maximum of their physical capacity unless chest pain, significant ST segment depression or elevation in non Q-wave lead, arrhythmia, or noncardiac symptoms led to premature termination of their exercise. A positive TMT was defined as horizontal or downsloping ST segment depression or elevation in non-Q wave lead of $1 \mathrm{~mm}$ for at least 60-80 millisecond after J-point in any of the 12 ECG leads, or progressive drop in blood pressure during the test ${ }^{2,5,11}$. TMT was considered negative only if the patient achieved at least $85 \%$ of their predicted maximal heart rate without ST segment depression or elevation.

Because patients with ST depression involving $\geq 5$ leads are more likely to have multivessels coronary artery disease (CAD) ${ }^{2,3,7,8}$, patients with abnormal coronary angiography were classified by TMT into two classes ( $A$ and $B$ ) according to numbers of leads showing ST segment depression.

Class A: Patients with ST depression involving $\geq 5$ leads.

Class B: Patients with ST depression involving $<5$ leads

\section{Cardiac Catheterization}

All patients underwent selective coronary angiography according to standard protocol (12). Angiographic data in this study were reviewed by at least three experienced observers who were completely unaware of the results of TMT. A $70 \%$ stenosis in the lumen diameter of coronary arteries or $50 \%$ stenosis of left main stem was considered critical lesion ${ }^{13}$.

Coronary artery lesions were categorized in to 4 groups according to the identity of vessel involved, site of lesions in the vessels and to the number of vessels involved. This division takes on consideration the size of jeopardized myocardium affected by these lesions, where the size of myocardium supply by left main stem (LMS) is larger than that supplied by left circumflex (LC), anterior descending artery (LAD) or the right coronary artery (RCA) separately. Also, LAD artery supplies larger area of myocardium than those in RCA or LCX ${ }^{14}$.

\section{These groups are:}

I. Patients with a lesion in LMS and/or a lesion in ostial or proximal LAD in addition to at least a single lesion in another main coronary artery.

II. Patient with critical lesion in ostial or proximal LAD alone.

III. Patients with critical lesions in at least 2 main coronary vessels in mid site or more distally

IV. Patient with critical lesions other than that included in group I, II or III. 
The area of jeopardized myocardium in these groups is represented in a descending order of magnitude.

The correlation between angiographic groups with results of TMT were studied.

The statistical analysis used in this study were percentage test and chi-square test $\left(X^{2}\right)$. Value of $P$ less than 0.05 was deemed as statistically significant.

\section{RESULTS}

Treadmill exercise testing (TMT) was truly positive in 47 patients, falsely positive in 4 patients, while it was truly negative in 10 patients and falsely negative in 14 patients (Figure 1). The sensitivity of TMT was $77 \%$, while the specificity of test was $71.5 \%$. The positive predictive value was $92 \%$, while negative predictive value $41.5 \%$. The likehood ratio of positive TMT (LRT) was 2.69. The test accuracy was $76 \%$.

The number of patients with significant coronary angiographic changes in class $\mathrm{A}$ (patients with $\geq 5$ leads ST depression in TMT) was 31 (50.8\%), while in class B (patients with $<5$ leads ST depression in TMT) was 30 patients $(49.2 \%)$ Table (3a).

The groups of coronary angiographic changes in relation to class $A$ and class $B$ are shown in table 1.Table 2 shows the same groups of patients after excluding those patients with $\mathrm{Ml}$ and/or those developing STA at low workload precluding the continuation of the test.

In group I, the total number of patients was 14 patients, 10 patients $(71.5 \%)$ were in class $A$, while $4(28.5 \%)$ patients were in class B (Table 1$)$. After excluding $\mathrm{Ml}$ and patients with STA at low workload, all patients in group I became in calss $A$ $(100 \%)$. In group II, the total number was 10 patients, 6 patients $(60 \%)$ were in class $A$, while 4 patients $(40 \%)$ were in class $B$ (Table 1$)$. When excluding patients with $\mathrm{MI}$ and those with STA, the total number of patients in this group became 6 , all of them fall in class A (100\%) (Table 2).

In group III, the total number was 20 patients, 10 patients $(50 \%)$ in class $A$ and 10 patients $(50 \%)$ in class B (Table 1). After excluding patients with $\mathrm{MI}$ and with STA, the patients in class $A$ became 10 $(83 \%)$ and in class B 2 patients (17\%) (Table2).

In group IV, the total number was 17 patients, 12 patients $(70.6 \%)$ were in class $B$ and 5 patients
(29.4\%) in class A (Table 1). When excluding both $\mathrm{MI}$ and STA, the patients in class $\mathrm{B}$ became 8 $(62 \%)$ while in class A became $5(38 \%)$ patients (Table 2). In class A of this group, 3 patients, each of them had collection of 3 large arteries with significant lesions (although not all were main coronary arteries), where one of these patients had mid critical lesion in LAD after first big diagonal branch (D1) and this first big diagonal branch had ostial lesion and this makes it equivalent to proximal $L A D$, in addition to critical lesion in distal LCX in same patients. The second patient had mid critical lesion in LAD, in addition to total cut of distal LCX after second obtuse marginal branch (OM2) and critical lesion in big (OM1) and this can be equivalent to critical lesion in mid LCX, in addition to mid critical lesion of LAD. This can be equal to those patients included in group III. The third patient had long mid critical lesion in RCA, ostial critical lesion in large D1 and long critical lesion in large OM1. After excluding these 3 patients from class $A$ of group IV, because their coronary lesions affected large size of myocardium equivalent to these lesions in group II or III, the total number of patients in group IV became 10 patients, 8 of them $(80 \%)$ in class $B$ and 2 patients $(20 \%)$ in class $A$ (Table 2). These 2 patients (in class $A$ of group IV) have mid critical lesion in LAD alone. In this study only seven patients had isolated mid LAD lesion, only 2 of them $(28.5 \%)$ were in class $A$, while 5 patients $(71.5 \%)$ in class $B$, with $P$-value $<0.040$.

There were statistically significant differences between group IV and ach of group I, II or III separately in relation to class $A$ or class $B$, and especially after excluding patients with $\mathrm{Ml}$ and those with STA at low workload. Also, the differences were significant between group IV and the collections of the first 3 groups (I, II and III) in relation to class $A$ and class $B($ Table 1,2$)$. There were no significant differences between group I, II and III, even after excluding patient with $\mathrm{MI}$ and STA at low workload. 


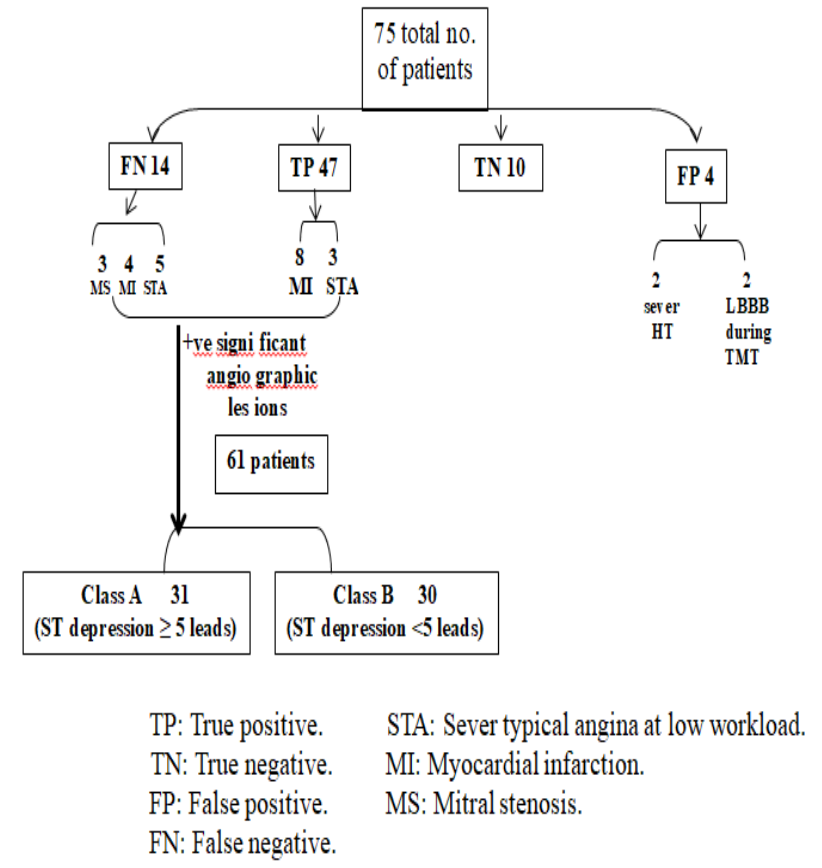

Figure 1: Result of exercise test correlated with significant angiographic lesions

Table (1): All patients in the angiographic groups including those with $\mathrm{MI}$ and STA.

\begin{tabular}{|c|c|c|c|c|c|c|c|}
\hline $\begin{array}{c}\text { Angi } \\
\text { o- } \\
\text { grap } \\
\text { hic } \\
\text { grou } \\
\text { p }\end{array}$ & $\begin{array}{c}\text { No. } \\
\text { of } \\
\text { ntie } \\
\text { grou } \\
\text { p }\end{array}$ & $\begin{array}{c}\text { Pati } \\
\text { ent } \\
\text { with } \\
\text { MI }\end{array}$ & $\begin{array}{c}\text { STA } \\
\text { at low } \\
\text { workl } \\
\text { oad }\end{array}$ & $\begin{array}{c}\text { Pati } \\
\text { ent } \\
\text { in } \\
\text { clas } \\
\text { s A }\end{array}$ & $\begin{array}{c}\text { Pati } \\
\text { ent } \\
\text { in } \\
\text { clas } \\
\text { s B }\end{array}$ & $\begin{array}{c}\text { P- } \\
\text { valu } \\
\text { e } \\
\text { for } \\
\text { clas } \\
\text { s A }\end{array}$ & $\begin{array}{c}\text { P- } \\
\text { valu } \\
\text { e } \\
\text { for } \\
\text { clas } \\
\text { s B }\end{array}$ \\
\hline $\begin{array}{c}\text { I and } \\
(\%)\end{array}$ & 14 & 4 & 1 & $\begin{array}{c}10 \\
(71.5 \\
\%)\end{array}$ & $\begin{array}{c}4 \\
(28.5 \\
\%)\end{array}$ & $\begin{array}{c}* 0.0 \\
26\end{array}$ & $\begin{array}{c}* 0.0 \\
26\end{array}$ \\
\hline $\begin{array}{c}\text { II } \\
\text { and } \\
(\%)\end{array}$ & 10 & 3 & 1 & $\begin{array}{c}6 \\
(60 \% \\
(1)\end{array}$ & $\begin{array}{c}4 \\
(40 \% \\
)\end{array}$ & $\begin{array}{c}* 0.1 \\
30\end{array}$ & $\begin{array}{c}* 0.1 \\
25\end{array}$ \\
\hline $\begin{array}{c}\text { III } \\
\text { and } \\
(\%)\end{array}$ & 20 & 5 & 3 & $\begin{array}{c}10 \\
(50 \% \\
(5)\end{array}$ & $\begin{array}{c}10 \\
(50 \% \\
)\end{array}$ & $\begin{array}{c}* 0.2 \\
09\end{array}$ & $\begin{array}{c}0.20 \\
9\end{array}$ \\
\hline $\begin{array}{c}\text { IV } \\
\text { and } \\
(\%)\end{array}$ & 17 & 3 & 1 & $\begin{array}{c}5 \\
(29.4 \\
\%)\end{array}$ & $\begin{array}{c}12 \\
(70.6 \\
\%)\end{array}$ & $\begin{array}{c}\# 0.0 \\
39\end{array}$ & $\begin{array}{c}\# 0.0 \\
39\end{array}$ \\
\hline
\end{tabular}

* P - value when comparing with group IV.

\# P-value for overall group I, II \& III comparing with group IV.

After excluding MI and STA, the result become more significant.
Table (2): Patients without MI and STA at low workload.

\begin{tabular}{|c|c|c|c|c|c|}
\hline $\begin{array}{c}\text { Angio- } \\
\text { graphic } \\
\text { group }\end{array}$ & $\begin{array}{c}\text { No. of } \\
\text { patients } \\
\text { in } \\
\text { group }\end{array}$ & $\begin{array}{c}\text { Patient } \\
\text { in } \\
\text { class } \\
\text { A }\end{array}$ & $\begin{array}{c}\text { Patient } \\
\text { in } \\
\text { class } \\
\text { B }\end{array}$ & $\begin{array}{c}\text { P-value } \\
\text { for } \\
\text { class A }\end{array}$ & $\begin{array}{c}\text { P-value } \\
\text { for } \\
\text { class B }\end{array}$ \\
\hline $\begin{array}{c}\text { I and } \\
(\%)\end{array}$ & 9 & $\begin{array}{c}9 \\
(100 \%)\end{array}$ & $\begin{array}{c}0 \\
(0 \%)\end{array}$ & $\begin{array}{c}{ }^{*} 0.008 \\
0.002\end{array}$ & $\begin{array}{c}{ }^{*} 0.007 \\
0.002\end{array}$ \\
\hline $\begin{array}{c}\text { II and } \\
(\%)\end{array}$ & 6 & $\begin{array}{c}6 \\
(100 \%)\end{array}$ & $\begin{array}{c}0 \\
(0 \%)\end{array}$ & $\begin{array}{c}{ }^{*} 0.023 \\
0.008\end{array}$ & $\begin{array}{c}{ }^{*} 0.021 \\
{ }^{*}\end{array}$ \\
\hline $\begin{array}{c}\text { III and } \\
(\%)\end{array}$ & 12 & $\begin{array}{c}10 \\
(83 \%)\end{array}$ & $\begin{array}{c}2 \\
(17 \%)\end{array}$ & $\begin{array}{c}{ }^{*} 0.031 \\
0.007\end{array}$ & $\begin{array}{c}{ }^{*} 0.031 \\
0.007\end{array}$ \\
\hline $\begin{array}{c}\text { IV and } \\
(\%)\end{array}$ & 13 & $\begin{array}{c}5 \\
(38 \%)\end{array}$ & $\begin{array}{c}8 \\
(62 \%)\end{array}$ & $\# 0.0006$ & $\# 0.0006$ \\
\hline $\begin{array}{c}\text { IV and } \\
(\%)\end{array}$ & 10 & $\begin{array}{c}2 \\
(20 \%)\end{array}$ & $\begin{array}{c}8 \\
(80 \%)\end{array}$ & 0.0001 & $\begin{array}{c}\# 1 \\
0.0001\end{array}$ \\
\hline
\end{tabular}

* P - value when comparing with group IV.

\# P-value for overall groups I, II \& III comparing with group IV.

*1 After exclude patients with lesions in 3 large branches (see text).

$\square$ IV group IV after excluding those patients with lesions in 3 large branches.

\#1: P-value for overall group I, II \& III comparing with group IV after exclude patients with lesions in 3 large branches (see text).

The overall percentage of first 3 groups (I, II, III) in class A was $84 \%$, while the percentage of group IV in class $A$ was $16 \%$. For class $B$ the percentage of first 3 groups collectively was $60 \%$, while in group IV $40 \%$ (Table 3a). The difference between class A and class $B$ in overall first 3 groups was not significant (P 0.371) (Table 3a). 
Table (3a): TMT classification

\begin{tabular}{|c|c|c|c|c|c|}
\hline $\begin{array}{l}\text { TMT } \\
\text { Classe } \\
\text { s }\end{array}$ & $\begin{array}{l}\text { Total } \\
\text { no. of } \\
\text { patie } \\
\text { nt }\end{array}$ & $\begin{array}{l}\text { Group } \\
\text { I no. } \\
\text { of } \\
\text { patien } \\
t\end{array}$ & $\begin{array}{l}\text { Group } \\
\text { II no. } \\
\text { of } \\
\text { patien } \\
t\end{array}$ & $\begin{array}{l}\text { Group } \\
\text { III no. } \\
\text { of } \\
\text { patien } \\
t\end{array}$ & $\begin{array}{l}\text { Grou } \\
p \quad \text { IV } \\
\text { no. of } \\
\text { patie } \\
\text { nt }\end{array}$ \\
\hline $\begin{array}{l}\text { Class } \\
\text { A \& } \\
(\%)\end{array}$ & $\begin{array}{l}31 \\
(100 \% \\
)\end{array}$ & $\begin{array}{l}10 \\
(32.3 \\
\%)\end{array}$ & $\begin{array}{l}6 \\
(19.3 \\
\%)\end{array}$ & $\begin{array}{l}10 \\
(32.3 \\
\%)\end{array}$ & $\begin{array}{l}5 \\
(16 \%)\end{array}$ \\
\hline $\begin{array}{l}\text { Class } \\
\text { B \& } \\
(\%)\end{array}$ & $\begin{array}{l}30 \\
(100 \% \\
)\end{array}$ & $\begin{array}{l}4 \\
(13.3 \\
\%)\end{array}$ & $\begin{array}{l}4 \\
(13.4 \\
\%)\end{array}$ & $\begin{array}{l}10 \\
(33.4 \\
\%)\end{array}$ & $\begin{array}{l}12 \\
(40 \%)\end{array}$ \\
\hline $\begin{array}{l}\text { P- } \\
\text { value }\end{array}$ & $\begin{array}{l}\# 0.37 \\
1\end{array}$ & 0.050 & 0.50 & 0.92 & 0.040 \\
\hline
\end{tabular}

\# P-value for correlation between class $A$ and $B$ in overall first 3 groups (I, II \& III).

After exclude $\mathrm{MI}$ and patient with STA at low workload the overall percentage of first 3 groups (I, II and III) in class A was (92.6\%), while in class B (20\%). The percentage of group IV in class A was $(7.4 \%)$, while in class B was $(80 \%)$. The differences between the overall first 3 groups (I, II \& III) in class $A$ and in class $B$ was significant ( $P$ 0.040) (Table $3 b$ ).

Table (3b): After exclude patient with MI \& STA at low workload.

\begin{tabular}{|l|l|l|l|l|l|}
\hline $\begin{array}{l}\text { TMT } \\
\begin{array}{l}\text { Class } \\
\text { es }\end{array}\end{array}$ & $\begin{array}{l}\text { Total } \\
\text { no. } \\
\text { of } \\
\text { patie } \\
\text { nt }\end{array}$ & $\begin{array}{l}\text { Grou } \\
\text { no. of } \\
\text { patie } \\
\text { nt }\end{array}$ & $\begin{array}{l}\text { Grou } \\
\text { p II } \\
\text { no. of } \\
\text { patie } \\
\text { nt }\end{array}$ & $\begin{array}{l}\text { Grou } \\
\text { no. of } \\
\text { patie } \\
\text { nt }\end{array}$ & $\begin{array}{l}\text { Grou } \\
\text { no. IV } \\
\text { of } \\
\text { patie } \\
\text { nt }\end{array}$ \\
\hline $\begin{array}{l}\text { Class } \\
\begin{array}{l}\text { A \& } \\
(\%)\end{array}\end{array}$ & $\begin{array}{l}27 \\
(100 \\
\%)\end{array}$ & $\begin{array}{l}9 \\
(33.3 \\
\%)\end{array}$ & $\begin{array}{l}6 \\
(22.2 \\
\%)\end{array}$ & $\begin{array}{l}10 \\
(37.1 \\
\%)\end{array}$ & $\begin{array}{l}2 \odot \\
(7.4 \% \\
)\end{array}$ \\
\hline $\begin{array}{l}\text { Class } \\
\text { B \& } \\
(\%)\end{array}$ & $\begin{array}{l}10 \\
(100 \\
\%)\end{array}$ & $\begin{array}{l}0 \\
(0 \%)\end{array}$ & $\begin{array}{l}0 \\
(0 \%)\end{array}$ & $\begin{array}{l}2 \\
(20 \%)\end{array}$ & $\begin{array}{l}8 \\
(80 \%)\end{array}$ \\
\hline $\begin{array}{l}\text { P } \\
\text { value }\end{array}$ & $\begin{array}{l}\# 0.04 \\
0\end{array}$ & 0.043 & 0.112 & 0.33 & $\begin{array}{l}0.000 \\
1\end{array}$ \\
\hline
\end{tabular}

(C) exclude those patients with lesions in 3 large branches (although not all are main branches) see text.

\# P-value for correlation between class $A$ and $B$ in overall first 3 groups (I, II \& III).
The correlation between class $A$ and class $B$ was statistically significant only in group I (P 0.05) and in group IV ( $P$ 0.040) table (3a). After excluding MI and STA at low workload, the $p$-values for class $A$ and $B$ were also significant only in group I (0.0433) and in group IV (0.0001) Table (3b).

\section{DISCUSSION}

In this study, we took a group of patients who were referred usually from specialized physician and cardiologist to our center, so most of these patients were diagnosed as having CAD or the probability of having CAD is high. This may account for the high positive predictive value $(92 \%)$, with the negative predictive value was low $(41.5 \%)^{15}$.

In this study there where 4 false positive patients, two of them had severe hypertension during TMT which was most probably the cause of false positive result ${ }^{16-18}$. Also, one from the remaining 2 patients developed left bundle branch block during TMT at a heart rate of $150 \mathrm{bpm}$, which also can be a cause for a false positive result. Bounhoure, et al. found that patients with complete left bundle branch block occurring at heart rate of more than $120 \mathrm{bpm}$ during exercise test were frequently associated with normal coronary angiography ${ }^{19}$. These 2 conditions explain why the specificity test in this study $(71.5 \%)$ was somewhat lower than expected as our patients were highly selected. The sensitivity was $(77 \%)$ including patients with previous $\mathrm{MI}$ which can decrease the sensitivity of test ${ }^{9}$.

In this study, we correlate the groups of angiographic changes with the result of TMT in 2 states, including those with $\mathrm{MI}$ and STA at low workload and without, because Ml can mask the ischemic ECG changes in $\mathrm{TMT}^{9}$. Peter, et al found that significant ECG changes during exercise test are blunted by the presence of previous $\mathrm{MI}^{20}$. Also, the development of STA at low workload and the early positivity in some patients in this study preclude the appearance of ST depression in further leads during TMT. Although the development of severe anginal pain at low workload (metabolic equivalents less than 5) during TMT itself indicates the presence of multivessel disease ${ }^{9}$. 
We noticed that group I which includes patients with severe angiographic changes with large size of jeopardized myocardium and group IV which includes patients with least severity of angiographic change and smallest size of jeopardized myocardium ${ }^{14}$, there were significant statistical difference between class A (STdepression involving $\geq 5$ leads) and class B (ST depression involving $<5$ leads), with $P$-value 0.05 and 0.040 , respectively (Table3a). After excluding $\mathrm{MI}$ and STA the difference became more significant with a P-value of 0.0433 in group I and 0.0001 in group IV(Table $3 b)$, but it is not significant when comparing class, A and B in group II or III, even after excluding patients with $\mathrm{Ml}$, and/or those with STA in whom severe angina preclude the completion of TMT.

Then when comparing each of group I, II or III with group IV regarding the significance of class $A$ or $\mathrm{B}$, we found that both classes were significant when we compared between groups I and IV. The $\mathrm{P}$-value was 0.02 for both class $\mathrm{A}$ and $\mathrm{B}$. After excluding $\mathrm{MI}$ and STA the $\mathrm{P}$-value became more significant $(P<0.015)$ for both class $A$ and $B$.

When we compared group II or III with group IV. We found no significance in relation to class $A$ or $\mathrm{B}$, but when excluding patient with $\mathrm{MI}$ and STA at low workload, both class $A$ and $B$ became significant with $\mathrm{P}$-value $<0.05$.

There was no significant difference in first 3 groups (I, II, III) in relation to class A or B when compared with each other, even after excluding patients with $\mathrm{Ml}$ and/or patient with STA at low workload. Because the coronary lesions in each of the first 3 groups affect large size of myocardium with significant jeopardizes myocardium relative to group IV. So, when we considered the first 3 groups (I, II, III) collectively as a single group and compared with IV, we noticed significant difference between them regarding to both class $\mathrm{A}$ or $\mathrm{B}$ with a $P$-value of (0.039) (Table1), and after excluding patients with $\mathrm{MI}$ and STA. the difference became more significant $(<0.0006$ and $<0.0006)$ for class $A$ and $B$, respectively (Table2).

The present study, shows that $84 \%$ of patient who have ST depression on 5 leads or more (class A) were included in first 3 groups, while it only $16 \%$ in group IV, but this is not significant when compared with patient with ST depression involving less than 5 leads (class B), where $60 \%$ of them were in first 3 groups and $40 \%$ in group IV. But after excluding patient with $\mathrm{MI}$ and STA, about $93 \%$ of patients in class A were in the first 3 groups and $7 \%$ only fall in group IV and when compared dwith class $B$, only $20 \%$ were in first 3 groups and $80 \%$ fall in group IV with statistically significant differences $(\mathrm{P}<0.04)$ (Table3a).

There were 3 patients whose angiographic lesion did not fit that present in group I, II or III, albeit they were included in group IV, but their coronary artery lesions can jeopardize size of myocardium equivalent to that happen in group II and III.

From this study, it could be possible to say that patients with ST depression in 5 leads or more during exercise test are more likely to have coronary artery lesions severe enough to jeopardize large size of myocardium while those whose exercise ECG test shows ST depression in less than 5 leads and who have no previous MI with normal pretest ECG and especially if they could carry on with the test to the end are more likely to have less severe coronary artery lesions with small jeopardized myocardium rather than to say that these patients have lesions in specific main coronary arteries or that definite number of coronary arteries are involved. That, because we noticed that each group can involve different identities of coronary arteries and different number, but the groups differ among each other regarding the size of jeopardized myocardium which could be considered the culprit in determining the number of leads which develop ST depression during TMT.

The limitation of this study was the relatively small number of patients who were included, large number of patients go to catheterization laboratory without doing exercise test. Moreover, some exercise ECG tests performed in this hospital are not for diagnostic indication but for follow-up and prognostic purposes (e.g. following $\mathrm{PCl}$ ).

\section{CONCLUSION}

Our data suggest that exercise ECG test can be useful in determining the severity of coronary artery disease and the size of jeopardized myocardium rather than which coronary artery is involved or the location of lesions or number of vessels involved. 


\section{REFERENCES}

1. Fletcher GF, Ades PA, Kligfield P, et al. Exercise standards stesting and trianing: a scientific statement from the American Heart Association. Circulation 2013; 128:873.

2. Gibbons RJ, Balady GJ, Bricker JT, et al. ACC/AHA 2002 guideline update for exercise testing. Summary article. A report of the ACC/AHA task force or practice guidelines (Committee to update the 1997 exercise testing guideline). J Am Coll Cardiol 2002; 40: 1531.

3. Fletcher GF, Balady GJ, Amsterdam EA, et al. Exercise standards for testing and training: $A$ statement for health care professionals from the American Heart Association. Circulation 2001; 104: 1694

4. Uthamalingam $S$, zheng $H$, leavi $H$, et al. Exercise -induced ST -segment elevation in ECG lead avR is a useful indication of significant left main or osteal LAD coronary artery stenosis. JACC cardiovascular imaging 2011; 4:176.

5.Skjaeggestad $O$, Johansen $O$, Arnesen $H$. Exercise ECG and localization of coronary artery stenosis. Tidsskr Nor Lacgeforen 2004; 2: 30668 (Medline).

6.Bernard R. Exercise stress testing. In: Braunwald E, Douglas P, Libby $\mathrm{P}$, eds. Heart disease $9^{\text {th }}$ ed. Philadelphia: WB Saunders; 2008: 168.

7.Pink staff S. Peberdy M.A., Kontos M.C., Finucane S, Arena R. Quantifying exertion level during exercise stress test using percentage age-predicted maximal heart rate, rate pressure product, and perceived exertion. Myo clin proc.2010;85(12):1095-1100. [PMC Free article] [Pub Med]

8. Froelicher VF, Myers J. Exercise and the Heart. $4^{\text {th }}$ ed. Philadelphia: WB Saunders; 2000.

9.Bernard R. Exercise stress testing. In: Douglas P, Robert O, Braunwald E, eds. Braunwald's heart disease $7^{\text {th }}$ ed. Philadelphia: Saunders; 2005: 153-173.

10. Christopher C. Exercise electrocardiographic testing. In: Marso SP, Griffin BP, Topol EJ, eds. Manual of cardiovascular medicine 2nd ed. Philadelphia: Lippincott Williams and Wilkins; 2004: 557.

11. Fearon WF, Lee DP, Froelicher VF. The effect of resting ST segment depression on the diagnostic characteristics of exercise treadmill testing. J Am Coll Cardiol 2000; 35: 1026.

12. Donald S, Grossman W. coronary Angiography. In: Donald S. Grossman W, eds. Grossman's cardiac catheterization. Angiography, and Intervention $6^{\text {th }}$ ed. Philadelphia: Lippincott Williams and Wilkins; 2000: 211.
13. Smith S, Dove J, Jacob A, et al. ACC/AHA guidelines of percutaneous coronary interventions (revision of the 1993 PTCA guidelines). Executive summary. A report of the American College of Cardiology / American Heart Association Task Force on Practice guidelines (Committee to revise the 1993 guidelines for percutaneous transluminal coronary angioplasty). J Am Coll Cardiol 2001; 37: 2215

14. William D. Applied anatomy of the heart. In: Robert O, Valentin F, Emililio R, eds. Cardiology: Fundamentals and Practice $1^{\text {st }}$ ed. Chicago: Year Book Medical Publisher, INC; 1987: 96-8.

15. Schwartz S. Clinical decision - making in cardiology. In: Douglas P, Robert O, Braunwald $\mathrm{E}$, eds. Braunwal'ds heart disease 7th ed. Philadelphia: Saunders; 2005: 27.

16. Miyai N, Arita M, Miyashita K, et al. Blood pressure response to heart rate during exercise test and risk of future hypertension. Hypertension 2002; 39: 761.

17. Singh JP, Larson MG, Manalia TA, et al. Blood pressure response during treadmill testing as risk factor for new-onset hypertension. The Framingham Study. Circulation 1999; 99: 1831.

18. Allison TG, Corderio MA, Miller TD, et al. Prognostic significance of exercise - induced systemic hypertension in healthy subjects. $A m \mathrm{~J}$ Cardiol 1999; 83: 371.

19. Biagini E, Show L, Poldermans D, et al. Accuracy of non-invasive technigues for diagnosis of coronary artery disease and predictor of cardiac events in patients with left bundle branch block : ameta-analysis. Eur J Nucl Med Mol imaging $2006 ; 33: 1442$.

20. Peter B, Jean G, Serge S, et al: A reappraisal of exercise electrocardiographic index of the severity of ischemic heart diseas: Angiographic and scintigraphic correlates. J Am Coll Cardiol 1997; 29: 1497-1504. 